\title{
openheart Are valve clinics a sound investment for the health service? A cost-effectiveness model and an automated tool for cost estimation
}

\author{
Adrian Ionescu, ${ }^{1}$ Charlie McKenzie, ${ }^{1}$ John B Chambers ${ }^{2}$
}

To cite: Ionescu A, McKenzie C, Chambers JB. Are valve clinics a sound investment for the health service? A cost-effectiveness model and an automated tool for cost estimation. Open Heart 2015;2:e000275. doi:10.1136/openhrt-2015000275

Received 2 April 2015 Revised 10 August 2015 Accepted 8 September 2015

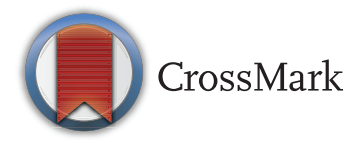

\footnotetext{
${ }^{1}$ Morriston Regional Cardiac Centre, Swansea, Wales, UK 'Guy's and St Thomas' Foundation Trust, London, UK
}

Correspondence to Dr Adrian Ionescu; Adrian.Ionescu@wales.nhs.uk

\section{ABSTRACT}

Background: Valve disease is using up an important, growing proportion of the resources allocated for healthcare. Clinical care is often suboptimal and while multidisciplinary clinics are the 'gold standard', their adoption has been patchy and inhomogeneous.

Methods: We hypothesised that adoption of valve clinics can deliver financial savings and set out to estimate differences in cost between a standard model in which the cardiologist sees every case and a multidisciplinary model in which some cases are devolved to sonographer-led or nurse-led clinics, assuming usage of various tests in accordance with practice at our institutions and to published data. We developed a tool that allows the modelling of limitless permutations in order to assess costs.

Results: Seeing 100 new patients in a valve clinic is more expensive than seeing them in the conventional set-up (excess cost £2700, \$4252). Follow-up of both patients with native valve disease (maximal savings/ 100 patients—£5166, \$8135) and with operated valves (maximal savings/100 patients— $-5090, \$ 8015$ ) is cheaper in a valve clinic than in a general cardiology clinic and the savings offset the increased cost of seeing new patients in the valve clinic.

Conclusions: The costing implications of valve clinics need to be worked out carefully. Our analysis suggests that important savings in healthcare costs could be achieved by their adoption. Clarifying the economic implications of this new model of care should become one of the priorities for the 'heart valve community'.

\section{INTRODUCTION}

The incidence of degenerative valve disease is increasing as our populations age. ${ }^{1}$ The population prevalence is about $2.5 \%$, but may be as high as $13 \%$ in those aged 75 and older. $^{2}$ It is well recognised that the organisation of clinical care is suboptimal ${ }^{3}$ with wide variations in access to appropriate medical care and surgery. Specialist multidisciplinary clinics are seen as best practice ${ }^{45}$ with a hub in 'surgical centres of excellence ${ }^{6} 7$ and spokes in district hospitals or the community.

\section{KEY QUESTIONS}

What is already known about this subject?

- There is a burgeoning literature on valve clinics, but very little data on their financial implications for the healthcare system. No clear conclusions about their impact on hospital finances can be drawn from the available literature.

What does this study add?

- In an age of austerity, this study looks at the impact of opening a valve clinic on the finances of a real-world department of cardiology, by modelling patient throughput as well as costs and savings.

How might this impact on clinical practice?

- This paper is the starting point for a debate in the valve community regarding the practicalities and the financial implications of switching from the current model of care to a valve clinic-based one. The costing tool can be obtained from the authors and adapted for use in any clinical setting where valve clinics are operating or are being planned.

However, the uptake of such clinics is incomplete, $21 \%$ in the UK. ${ }^{8}$ The UK has developed devolved surveillance in which senior nurses or sonographers monitor patients with uncomplicated valve disease before and after surgery (table 1). One obstacle in developing such services is the lack of costeffectiveness analyses. Here, we estimate the cost-saving likely from a multidisciplinary model run jointly by a cardiologist, sonographer and nurse. This may provide an aid to developing a business case for a clinic.

\section{METHODS \\ Staff levels}

We estimated differences in cost of a standard model in which the cardiologist sees every case and two models for a 
Table 1 Summary of roles in the valve clinic

\begin{tabular}{ll}
\hline Role & Staff \\
\hline $\begin{array}{l}\text { New visits. Referral for surgery if } \\
\text { necessary }\end{array}$ & Cardiologist \\
$\begin{array}{l}\text { Assessment of follow-up patient } \\
\text { with alerts. Referral for surgery as }\end{array}$ & Cardiologist \\
necessary & \\
Follow-up history & Nurse/sonographer \\
$\begin{array}{l}\text { Performing exercise test } \\
\text { Supervision of exercise test }\end{array}$ & $\begin{array}{l}\text { Exercise physiologist } \\
\text { Nurse/sonographer/ } \\
\text { cardiologist }\end{array}$ \\
Echocardiogram & $\begin{array}{l}\text { Sonographer/ } \\
\text { cardiologist } \\
\text { Brain natriuretic peptide test }\end{array}$ \\
& $\begin{array}{l}\text { Nurse/cardiologist/ } \\
\text { sonographer }\end{array}$ \\
\hline
\end{tabular}

multidisciplinary clinic in which some cases are devolved to sonographer-led or nurse-led clinics (table 2).

In all models, we assumed that two administrative and clerical staff would be used, and we included costs for two healthcare support workers in the consultant-led, conventional model, to reflect current realities in UK clinics.

For each of the models, we assessed the costs for seeing the following categories of patients:

A. New patients, who all need to be seen by the consultant, as in the current 'conventional' model, but we specified that instead of the $5 \%$ who currently have exercise tests, a much higher proportion $(50 \%)$ should have exercise tolerance tests (ETTs);

B. Follow-up patients with native valve pathologies;

C. Follow-up patients with operated valves.

In groups (B) and (C), we devolved a substantial proportion of patients to follow-up by non-medical staff. We specified that a lower proportion $(10 \%)$ of patients in group $(\mathrm{C})$ would need to see the cardiologist than in group (B) $-25 \%$, as the valve operation generally removes the risk of progression of valve pathology, and we assumed that $5 \%$ of all patients being followed up would need ETT during follow-up in order to assess objectively any new symptoms that may have developed during follow-up.

We used standard national tariffs for costing the echocardiograms and the exercise tests, and top of the scale figures for the salaries of the various staff categories involved. We specified a senior (band 8) sonographer for the sonographer-led clinic, and a senior nurse (band 8 ) working with a band 6 sonographer for the nurse-led clinic.

Final cumulative costs are given in GB£ and in US\$, rounded to the nearest decimal. The main savings are expected to be the cost of cardiologist time and in reducing unnecessary echocardiograms. ${ }^{9}$

Taggu et al showed that physician visits fell by $97 \%$, from 998 to 31 in a year. However, $5 \%$ of patients from the surveillance clinics need to be seen by the cardiologist because of a new symptom or change in echo, ${ }^{10}$

Table 2 Assumptions regarding proportion of patients undergoing different tests and requiring consultant review in each of the models

\begin{tabular}{|c|c|c|c|c|}
\hline \multicolumn{5}{|l|}{ New cases $(\mathrm{N}=100)$} \\
\hline & \multicolumn{2}{|c|}{$\begin{array}{l}\text { Old model } \\
\text { Consultant-led }\end{array}$} & \multicolumn{2}{|r|}{$\begin{array}{l}\text { New model } \\
\text { Sonographer-led }\end{array}$} \\
\hline See cardiologists & \multicolumn{2}{|c|}{100} & \multicolumn{2}{|r|}{100} \\
\hline Have echo & \multicolumn{2}{|c|}{100} & \multicolumn{2}{|r|}{100} \\
\hline Have ETT & \multicolumn{2}{|c|}{5} & \multicolumn{2}{|r|}{50} \\
\hline See other staff & \multicolumn{2}{|c|}{0} & & 0 \\
\hline & \multirow{2}{*}{$\begin{array}{l}\text { Old model } \\
\text { Consultant-led }\end{array}$} & \multicolumn{3}{|l|}{ New models } \\
\hline Native valve disease $(\mathrm{N}=100)$ & & Sonographer-only & Son & grapher and nurse \\
\hline \multicolumn{5}{|c|}{ Follow-up cases ( $\mathrm{N}=100$ for each category, ie, native and operated valve disease) } \\
\hline See cardiologists & 100 & 25 & 25 & \\
\hline See nurse & 0 & 0 & 75 & \\
\hline See sonographer & 0 & 75 & 0 & \\
\hline Have echo & 100 & 25 & 25 & \\
\hline Have ETT & 5 & 5 & 5 & \\
\hline Operated valve disease $(\mathrm{N}=100)$ & Consultant-lec & Sonographer only & \multicolumn{2}{|c|}{ Sonographer and nurse } \\
\hline See surgeon/cardiologist & 100 & 10 & \multicolumn{2}{|l|}{10} \\
\hline See nurse & 0 & 0 & \multicolumn{2}{|l|}{90} \\
\hline See sonographer & 0 & 90 & \multicolumn{2}{|l|}{0} \\
\hline Have echo & 100 & 25 & \multicolumn{2}{|l|}{25} \\
\hline Have ETT & 5 & 5 & \multicolumn{2}{|l|}{5} \\
\hline
\end{tabular}


Table 3 Staff-related costs for one follow-up consultation in the valve clinic, in each of the three models

\begin{tabular}{|c|c|c|c|c|c|c|c|c|}
\hline Staff involved & $\begin{array}{l}\text { Gross } \\
\text { cost }\end{array}$ & $\begin{array}{l}\text { Cost/productive } \\
\text { hour }\end{array}$ & \multicolumn{2}{|l|}{ Consultant } & \multicolumn{2}{|l|}{$\begin{array}{l}\text { Senior } \\
\text { sonographer }\end{array}$} & \multicolumn{2}{|c|}{$\begin{array}{l}\text { Sonographer } \\
\text { and staff nurse }\end{array}$} \\
\hline & & & $0.25 \mathrm{~h}$ & & $0.75 \mathrm{~h}$ & & $0.75 \mathrm{~h}$ & \\
\hline & & & WTE & & WTE & & WTE & \\
\hline Band 6 sonographer & 44570 & 26 & & & & & 1 & 19.38 \\
\hline Band $8 a$ nurse & 60780 & 35 & & & & & 1 & 26.43 \\
\hline $\begin{array}{l}\text { Band 8b } \\
\text { sonographer }\end{array}$ & 72934 & 42 & & & 1 & 31.71 & & \\
\hline Consultant & 120000 & 109 & 1 & 27.21 & & & & \\
\hline A\&C 2 & 22492 & 13 & 2 & 6.52 & 2 & 19.56 & 2 & 19.56 \\
\hline HCSW 2 & 22492 & 13 & 1 & 3.26 & & & & \\
\hline $\mathrm{SpR}$ & 57751 & 37 & 1 & 9.17 & & & & \\
\hline Consultation cost & & & & 46.16 & & 51.27 & & 65.36 \\
\hline
\end{tabular}

although the cardiology time needed is usually less than for a full visit as a result of the prior assessment by the sonographer or nurse. A further $10 \%$ require brief discussion by the sonographer or nurse with the cardiologist. A proportion of patients require follow-up with the cardiologist because of complex disease or proximity to thresholds for surgery. ${ }^{11}$

\section{Echocardiograms}

Compliance with guidelines is patchy and echocardiograms tend to be performed unnecessarily ${ }^{12-14}$ particularly after valve replacement. In some centres, ${ }^{9}$ all replacement valves are examined annually. We modelled the cost of an echocardiogram at $£ 74$ (\$117) which is the National Health Service (NHS) tariff, and we assumed that $100 \%$ of patients would have echos in the conventional model compared with $25 \%$ of those seen in a valve clinic.

\section{Other tests}

Exercise test are underutilised and requested in only about $10 \%$ of those in whom it would be indicated. ${ }^{15}$ This means that allowing 100 new patients of whom 50 might have asymptomatic severe disease, 5 tests might be performed using the conventional model and 50 using the new model. We assumed the cost of an ETT to be $£ 60$ (\$94), according to the NHS tariff. Numbers of chest X-ray, brain natriuretic peptide (BNP) estimation, Holter, CT were assumed to be similar in all groups and were therefore not included in the analysis.

All costs are expressed per 100 patients seen in the clinic.

\section{Automated costing tool}

We collated all the above information using a custommade Excel table (MS Office, 2007) with input cells corresponding to costs for individual components of each of the clinic configurations described, and with output cells configured to yield total costs in the various permutations of staff, access to tests and time needed to complete a consultation described above. The costing tool is available from the authors. Figures can be entered in the source cells, and the destination cells will update the costs accordingly (tables 3-7).

\section{RESULTS \\ New patients}

We found that the costs for seeing new patients were $£ 16811.34$ (\$26 472.82) in the conventional model and $£ 19631.34$ (\$18 838.47) in the valve clinic model (both consultant-led). The increase in cost was due entirely to the 10-fold increase in the proportion of patients referred to have exercise tests, in compliance with current guidelines.

\section{Follow-up: native valve disease}

The lowest cost was achieved in the sonographer-led clinic (£7149.06, \$11 257.61) and the highest in the

Table 4 Costs of seeing new patients in the conventional as opposed to the dedicated valve clinic

\begin{tabular}{lllll}
\hline & $\begin{array}{l}\text { Conventional } \\
\text { model }\end{array}$ & Valve clinic model \\
\hline Consultant-led & 100.00 & 9231.34 & 100.00 & 9231.34 \\
Refer for echo & 100 & 7400 & 100 & 7400 \\
Refer for ETT & 5 & 300 & 50 & 3000 \\
Total cost & 16931.34 & & 19631.34 \\
\hline $\begin{array}{l}\text { There is a 10-fold increase in the utilisation of ETT in the valve } \\
\text { clinic, and the time allocated to the consultant for one consultation } \\
\text { is 30 min as opposed to 15 min in the follow-up configuration. }\end{array}$
\end{tabular}


Table 5 Total costs incurred for seeing 100 follow-up patients with native valve disease in each of the models

\begin{tabular}{|c|c|c|c|c|c|c|}
\hline & \multicolumn{2}{|c|}{ Model $1-$ consultant-led } & \multicolumn{2}{|c|}{ Model 2-senior sonographer } & \multicolumn{2}{|c|}{$\begin{array}{l}\text { Model 3-sonographer and } \\
\text { nurse }\end{array}$} \\
\hline & $\begin{array}{l}\text { Percentage of } \\
\text { patients }\end{array}$ & Costs & $\begin{array}{l}\text { Percentage of } \\
\text { patients }\end{array}$ & Costs & $\begin{array}{l}\text { Percentage of } \\
\text { patients }\end{array}$ & Costs \\
\hline S/B consultant & 100 & 4615.67 & 25 & 1153.92 & 25 & 1153.92 \\
\hline S/B other staff & 0 & 0 & 75 & 3845.14 & 75 & 4902.18 \\
\hline Referred for echo & 100 & 7400 & 25 & 1850 & 25 & 1850 \\
\hline Referred for ETT & 5 & 300 & 5 & 300 & 5 & 300 \\
\hline Total cost & & 12315.67 & & 7149.06 & & 8206.10 \\
\hline
\end{tabular}

consultant-led clinic (£12 315.67, \$19 393.49), with the nurse-led clinic in an intermediate position $(£ 8206.10$, $\$ 12922.14)$.

\section{Follow-up: operated valve disease}

The same relative magnitude of costs was observed for postsurgical patients: To follow-up 100 such patients, the hospital would spend £7.225.73, \$11378.36 in the sonographer-led clinic; £12 315.67, \$19 393.49 in the consultant-led clinic; and £8494.18, \$13 375.73 in the nurse-led clinic.

\section{DISCUSSION}

This work shows that a multidisciplinary clinic is expected to save substantial sums. There is little previously published work. Extrapolating from the practice of one district general hospital gave an estimated yearly excess expenditure on unjustified echocardiograms in the UK of $£ 4.6$ million (£3 253 087; \$5 122 636). ${ }^{12}$ Turpie et $a l^{13}$ estimated that a surveillance clinic for aortic stenosis alone would achieve recurring savings in the UK amounting to $>9000$ avoided transthoracic echocardiographys (TTEs)/year suggesting a saving of some $£ 2$ million (\$3.14 million) if all types of valve disease are included. In the first study of this kind performed outside the USA, a survey of all the hospitals which perform echocardiography in Wales ${ }^{14}$ found that $11 \%$ of scans were requested for inappropriate indications, with 'routine' follow-up scans after valve replacement, a common reason for unnecessary studies.

\section{Other potential savings}

In a Canadian study, ${ }^{16}$ the rate of adherence to American Heart Association (AHA) guidelines varied between only $2 \%$ and $30 \%$, and adherence is also limited in the USA, ${ }^{17}$ Europe $^{15}$ and the UK. ${ }^{9}$ This means that surgery occurs late usually with class III or IV symptoms leading to prolonged intensive treatment unit and hospital stays, and very high costs incurred by the NHS along their care pathway. Specialist valve clinics detect symptoms earlier ${ }^{3}$ and have the potential to reduce costs drastically in this patient population by allowing timely referral for treatment.

There would be savings from lesser utilisation of hospital transport (average cost $£ 20$ (\$32) per journey) for the patient savings on car parking, days off work, time waiting to be seen. Imponderable savings include less easily quantifiable financial implications of valve clinics:

Ensuring that patients who have valves suitable for mitral repair are referred to surgeons able to perform repairs (this would increase the rate of mitral valve repair, currently rather low at $67 \%$ in the $\mathrm{UK}^{18}$ and would avoid need for prolonged anticoagulation, with its associated morbidity and costs).

Better dental surveillance with prevention of infective endocarditis (with the attending savings from avoiding very expensive and prolonged hospital admissions);

Table 6 Total costs incurred for seeing 100 follow-up patients with operated valve disease in each of the models

\begin{tabular}{|c|c|c|c|c|c|c|}
\hline & \multicolumn{2}{|c|}{ Model 1-consultant-led } & \multicolumn{2}{|c|}{ Model 2-senior sonographer } & \multicolumn{2}{|c|}{$\begin{array}{l}\text { Model 3-sonographer and } \\
\text { nurse }\end{array}$} \\
\hline & $\begin{array}{l}\text { Percentage of } \\
\text { patients }\end{array}$ & Costs & $\begin{array}{l}\text { Percentage of } \\
\text { patients }\end{array}$ & Costs & $\begin{array}{l}\text { Percentage of } \\
\text { patients }\end{array}$ & Costs \\
\hline $\begin{array}{l}\text { S/B } \\
\text { consultant }\end{array}$ & 100.00 & 4615.67 & 10.00 & 461.57 & 10.00 & 461.57 \\
\hline S/B other staff & 0 & 0 & 90.00 & 4614.16 & 90.00 & 5882.61 \\
\hline Refer for echo & 100 & 7400 & 25 & 1850 & 25 & 1850 \\
\hline Refer for ETT & 5 & 300 & 5 & 300 & 5 & 300 \\
\hline Total cost & & 12315.67 & & 7225.73 & & 8494.18 \\
\hline
\end{tabular}


Table 7 Summary of costs

\begin{tabular}{llrl}
\hline & Conventional model & Valve clinic model 1 & Valve clinic model 2 \\
\hline New patients & $£ 16811.34(\$ 26472.82)$ & $£ 19631.34(\$ 18838.47)$ & NA \\
Native valve follow-up & $£ 12315.67(\$ 19393.49)$ & $£ 7149.05(\$ 11257.61)$ & $£ 9020.10(\$ 14203.95)$ \\
Operated valve follow-up & $£ 12315.67(\$ 19393.49)$ & $£ 7225.73(\$ 11378.36)$ & $£ 9308.18(\$ 14657.60)$ \\
\hline
\end{tabular}

For new patients just one valve clinic configuration is considered (see text for explanation).

$\mathrm{NA}$, not available.

Improved anticoagulation control. Less time off work and a shift of the care model towards keeping patients out of hospital.

\section{Potential causes of higher costs}

We believe that there are few sources of increased cost except where corners are being cut by not following guidelines. If postoperative patients are discharged to the community, it will cost more in the short term to bring these to a clinic despite the prospect of longer term cost-savings provided by better care. Exercise testing is underutilised in Europe with approximately $10 \%$ of those suitable actually having a stress test. The time required for an echocardiogram may be longer in a valve clinic, typically 60 rather than $40 \mathrm{~min}$.

\section{LIMITATIONS}

This paper is meant to incite discussion and debate by trying to flesh out a more detailed assessment of costs and savings associated with heart valve clinics than the ones available so far in the literature. Because our figures are hypothetical, rather than derived from actual observation, they cannot be considered definitive. However, the assumptions we made are as close to the reality of contemporary UK clinical practice as possible. It was necessary to limit our findings to the UK context in order to be able to provide the level of detail that we were aiming for. This may make our findings somewhat parochial, but we think that the assumptions and the categories used in our calculations have the potential for generalisation in other systems, which the cost calculator should greatly facilitate.

We did not include outcome data because the primary focus of this paper was to analyse the financial implications of valve clinics; what little outcome data are available will be found in the references quoted.

\section{CONCLUSION}

There is a growing body of observational and circumstantial evidence supporting the notion that patientcentred care is best delivered to heart valve patients within the framework of valve clinics. The costing implications of valve clinics need to be worked out carefully, through multidisciplinary collaborations, but the available evidence suggests that significant costsavings can be achieved by avoidance of unnecessary echocardiograms and clinic visits, by the freeing of consultant time, by reducing the likelihood of delayed surgery with its associated morbidities and prolonged hospitalisations, and by avoidance of costly complications such as infective endocarditis. Clarifying the economic implications of this new model of care should become one of the priorities for the 'heart valve community'.

Contributors JBC suggested the topic and wrote the first draft. CM designed the costing tool and performed the preliminary analyses. Al performed the analyses that were included in the final version of the paper and responded to the comments of the reviewers, rewriting the paper in the current format.

Competing interests None declared.

Provenance and peer review Not commissioned; externally peer reviewed.

Data sharing statement The authors would like to make available the automated costing tool (an Excel table with cells customised to provide cost estimates for a virtually limitless number of permutations of the 'ingredients' comprised in a valve clinic) to the readers of the Journal. The costing tool is available to anyone interested, for free, on request from the corresponding author.

Open Access This is an Open Access article distributed in accordance with the Creative Commons Attribution Non Commercial (CC BY-NC 4.0) license, which permits others to distribute, remix, adapt, build upon this work noncommercially, and license their derivative works on different terms, provided the original work is properly cited and the use is non-commercial. See: http:// creativecommons.org/licenses/by-nc/4.0/

\section{REFERENCES}

1. d'Arcy JL, Prendergast BD, Chambers JB, et al. Valvular heart disease: the next cardiac epidemic. Heart 2011;97: 91-3.

2. Nkomo VT, Gardin JM, Skelton TN, et al. Burden of valvular heart diseases: a population-based study. Lancet 2006;368: 1005-11.

3. Chambers J, Lloyd G, Rimington HM, et al. The case for a specialist multidisciplinary valve clinic. J Heart Valve Dis 2012;21: $1-4$.

4. Chambers JB, Ray S, Prendergast B, et al. Specialist valve clinics: recommendations from the British Heart Valve Society working group on improving quality in the delivery of care for patients with heart valve disease. Heart 2013;99:1714-16.

5. Lancellotti $\mathrm{P}$, Rosenhek R, Pibarot $\mathrm{P}$, et al. ESC Working Group on Valvular Heart Disease position paper-heart valve clinics: organisation, structure and experiences. Eur Heart $J$ 2013;34:1597-606.

6. Vahanian A, Alfieri O, Andreotti F, et al. Joint Task Force on the Management of Valvular Heart Disease of the European Society of Cardiology (ESC); European Association for Cardio-Thoracic Surgery (EACTS). Guidelines on the management of valvular heart disease (version 2012). Eur Heart J 2012;33:2451-96.

7. Nishimura RA, Otto CM, Bonow RO, et al. American College of Cardiology; American College of Cardiology/American Heart Association; American Heart Association. 2014 AHA/ACC guideline for the management of patients with valvular heart disease: a report of the American College of Cardiology/American Heart Association Task Force on Practice Guidelines. J Thorac Cardiovasc Surg 2014;148:e1-32. 
8. Bhattacharyya S, Pavitt C, Lloyd G, et al. British Heart Valve Society. Provision, organization and models of heart valve clinics within the United Kingdom. QJM 2015;108:113-17.

9. Taggu W, Topham A, Hart L, et al. A cardiac sonographer-led follow up clinic for heart valve disease. Int $J$ Cardiol 2009;132:240-3.

10. Parkin D, Chambers J. Routine follow-up for patients with prosthetic valves: the value of a nurse-led valve clinic. Br J Cardiol 2012;19:204-6.

11. http://careers.bmj.com/careers/static/advice-salary-scales.htm (accessed 16 Sep 2013).

12. Zaidi A, lonescu A, Sharma R, et al. Echocardiographic surveillance of aortic valve stenosis: towards a standardized approach. $J$ Heart Valve Dis 2012;21:707-13.

13. Turpie D, Maycock M, Crawford C, et al. Establishing an aortic stenosis surveillance clinic. Br J Cardiol 2010;17:286-9.
14. Gurzun MM, lonescu A. Appropriateness of use criteria for transthoracic echocardiography: are they relevant outside the USA? Eur Heart J Cardiovasc Imaging 2014;15:450-5.

15. lung B, Baron G, Butchart EG, et al. A prospective survey of patients with valvular heart disease in Europe: the Euro Heart Survey on valvular heart disease. Eur Heart $J$ 2003;24: 1231-43.

16. Toledano K, Rudski LG, Huynh T, et al. Mitral regurgitation: determinants of referral for cardiac surgery by Canadian cardiologists. Can J Cardiol 2007;23:209-14.

17. Bach DS, Awais M, Gurm HS, et al. Valvular heart disease: failure of guideline adherence for intervention in patients with severe mitral regurgitation. J Am Coll Cardiol 2009;54:860-5.

18. Bridgewater B, Kinsman R, Walton P, et al. Demonstrating quality: the sixth National Adult Cardiac Surgery database report. Henley-on-Thames, UK: Dendrite Clinical Systems Ltd, 2009. 